\title{
ANALISIS HUBUNGAN PANJANG BOBOT DAN PENDUGAAN PARAMETER PERTUMBUHAN IKAN NILA (Oreochromis niloticus) DI WADUK IR. H. DJUANDA
}

\author{
Masayu Rahmia Anwar Putri dan Didik Wahju Hendro Tjahjo \\ Peneliti pada Balai Riset Pemulihan Sumber Daya Ikan, Jatiluhur-Purwakarta \\ Teregistrasi I tanggal: 1 Juli 2010; Diterima setelah perbaikan tanggal: 20 Juli 2010; \\ Disetujui terbit tanggal: 30 Juli 2010
}

\begin{abstract}
ABSTRAK
Ikan nila (Oreochromis niloticus) merupakan salah satu ikan introduksi yang mulai mendominansi hasil tangkapan ikan di Waduk Ir. H. Djuanda. Penelitian ini bertujuan untuk mengetahui hubungan panjang bobot dan menduga parameter pertumbuhan dari ikan nila di Waduk Ir. H. Djuanda. Contoh ikan didapatkan selama bulan Pebruari sampai Nopember 2008. Data panjang dan bobot ikan dianalisis hubungan panjang bobotnya dan ditentukan parameter pertumbuhannya dengan menggunakan program FISAT II. Hasil penelitian menunjukan bahwa pertumbuhan ikan nila di Waduk Ir. H. Djuanda bersifat allometrik negatif dengan persamaan $W=0,129 L^{2,4608}$, yang menandakan pertambahan bobotnya tidak secepat pertambahan panjangnya $(b<3)$ dengan faktor kondisi 1,15. Ukuran panjang ikan yang tertangkap berkisar antara 11-41 cm. Hasil pendugaan parameter pertumbuhan diperoleh $\mathrm{L} \infty=44,10 \mathrm{~cm}, \mathrm{~K}=0,72$ (per tahun), dengan $\mathrm{Z}=2,4, \mathrm{M}=1,34, \mathrm{~F}=1,06$, dan $\mathrm{E}=0,44$.
\end{abstract}

KATAKUNCl: hubungan panjang bobot, parameter pertumbuhan, Oreochromis niloticus, Waduk Ir. H. Djuanda

\begin{abstract}
Length weight relationship analysis and growth parameters estimation of nile tilapia (Oreochromis niloticus) in Ir. H. Djuanda Reservoir. By: Masayu Rahmia Anwar Putri and Didik Wahju Hendro Tjahjo
\end{abstract}

Nile tilapia (Oreochromis niloticus) is one of introduction fishes that begin to dominate yield of fish capture at Ir. H. Djuanda Reservoir. The aim of this research was to know the length weight relationship and growth parameters estimation of nile tilapia at Ir. H. Djuanda Reservoir. The samples were collected during February until November 2008. The length and weight data of nile tilapia were analyzed its length weight relationship and the growth parameters were evaluated by FISAT II. The research shows that the characteristic of nile tilapia growth's at Ir. H. Djuanda Reservoir was allometric negative with similarity $W=0.129 L^{2.4608}$, that indicated the increasing of weight from this fish not fast as its length $(b<3)$ with the condition factor of it was 1.15 . The range measure of fish length that captured was $11-41 \mathrm{~cm}$. The results from growth parameters estimation were $L_{\infty}=44.10 \mathrm{~cm}, K=0.72$ (per year), with $Z=2.4, M=1.34, F=1.06$, and $E=0,44$.

KEYWORDS: $\quad$ length weight relationship, growth parameters, Oreochromis niloticus, Ir. $\boldsymbol{H}$. Djuanda Reservoir

\section{PENDAHULUAN}

Sebagai salah satu waduk terbesar di Indonesia dengan volume air mencapai 3.200 juta $\mathrm{m}^{3}$ (Kartamihardja, 1990 dalam Kartamihardja, 2008), Waduk Ir. H. Djuanda merupakan lahan potensial untuk dijadikan sebagai sumber daya perikanan di Provinsi Jawa Barat. Untuk memanfaatkan potensi perikanan di Waduk Ir. H. Djuanda, sejak tahun 1976 telah dilakukan uji coba budi daya ikan di Waduk Ir. $\mathrm{H}$. Djuanda dengan menggunakan keramba jaring apung yang terus meningkat setiap tahunnya.

Kondisi ini mengakibatkan terjadinya penumpukan sisa pakan ikan yang kemudian terurai menjadi limbah dalam bentuk $\mathrm{N}$ dan $\mathrm{P}$ yang meningkatkan kandungan plankton. Untuk mengurangi keberadaan plankton dilakukan penebaran ikan yang dapat memakan plankton, salah satunya adalah ikan nila. Menurut Anonimus (2009), ikan nila merupakan ikan omnivora yang memanfaaatkan fitoplankton, periphyton, tumbuhan air, invertebrata kecil, fauna bentik, detritus, dan bakteri yang berasosiasi dengan detritus sebagai makanannya.

Ikan nila merupakan salah satu ikan air tawar yang mempunyai nilai ekonomis penting di Waduk Ir. $\mathrm{H}$. Djuanda di mana ikan ini telah menjadi komoditi ekspor perikanan dunia. Indonesia merupakan salah satu negara pengekspor ikan nila, bersama China, Ekuador, Kuba, dan Honduras. Sedangkan negaranegara yang tercatat sebagai pengimpor ikan nila adalah timur tengah, Singapura, Jepang, dan Amerika 
Serikat. Kebutuhan ikan nila Amerika Serikat cukup tinggi sedangkan produksi nila domestik di sana belum dapat memenuhi kebutuhan. Pada tahun 1998 impor ikan nila Amerika Serikat dari manca negara mencapai 45 ton dan pada tahun 1999 meningkat lagi 15\% atau sekitar 52 ton (Infofish, 2001 dalam Sucipto, 2009).

Analisis tentang hubungan panjang bobot ikan dan pendugaan parameter pertumbuhan sangat penting dalam perikanan sebagai informasi dasar untuk biologi perikanan dan dinamika populasi sehingga dapat menentukan pola pemanfaatan dan pengelolaan yang sesuai dengan sumber daya perikanan yang ada.
Tulisan ini dibuat dengan tujuan untuk mengetahui hubungan panjang bobot dan menduga parameter pertumbuhan dari ikan nila yang tertangkap di perairan Waduk Ir. H. Djuanda.

\section{BAHAN DAN METODE}

Penelitian ini dilakukan di Waduk Ir. H. Djuanda (Gambar 1) selama bulan Pebruari sampai Nopember 2008. Contoh ikan didapatkan dari hasil tangkapan nelayan melalui enumerator di Waduk Ir. H. Djuanda dengan menggunakan jaring insang dengan ukuran mata 2-4 inci. Ikan nila yang tertangkap diukur panjang dan bobotnya.

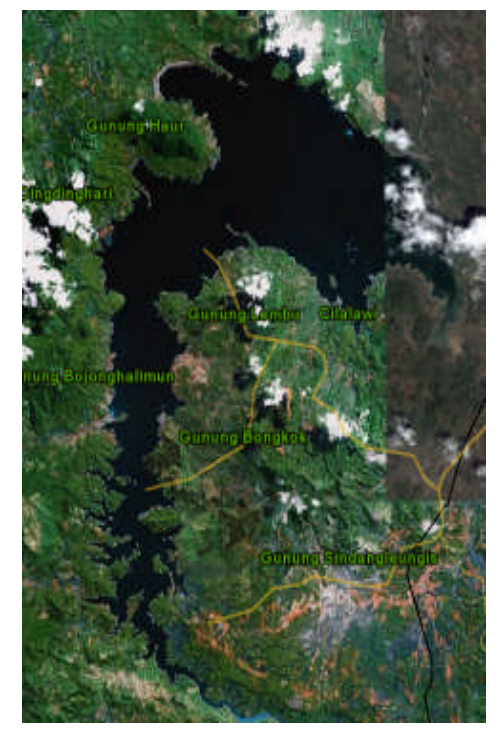

Gambar 1. Peta Waduk Ir. H. Djuanda.

Figure 1. Map of Ir. H. Djuanda Reservoir.

Pengukuran panjang total (total length) diukur dengan papan ukur dengan ketepatan $1 \mathrm{~cm}$ dan pengukuran bobot menggunakan timbangan ketepatan $0,1 \mathrm{~g}$. Parameter yang diamati antara lain distribusi panjang bobot, hubungan panjang bobot. Analisis hubungan panjang bobot menggunakan rumus sebagai berikut:

$$
\begin{array}{cl}
\mathrm{W}=a \mathrm{~L}^{\mathrm{b}} & \\
\text { di mana: } & \\
\mathrm{W} & =\text { bobot ikan }(\mathrm{g}) \\
\mathrm{L} & =\text { panjang ikan }(\mathrm{mm}) \\
\mathrm{a} \text { dan } \mathrm{b} & =\text { konstanta }
\end{array}
$$

Rumus umum tersebut bila ditranformasikan ke dalam logaritma, maka akan mendapatkan persamaan Log $W=\log a+b \log L$, yaitu persamaan linier atau persamaan garis lurus. Harga konstanta $b$ adalah

harga pangkat yang cocok dari panjang ikan agar sesuai dengan bobot ikan (Effendie, 1997).

Faktor kondisi dihitung menggunakan rata-rata panjang total dan bobot ikan nila. Persamaan rumus perhitungannya sebagai berikut (Effendie, 1979 dalam Handayani, 2006):

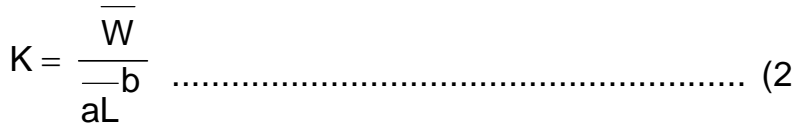

$$
\begin{aligned}
& \text { di mana: } \\
& \mathrm{K}=\text { faktor kondisi } \\
& \mathrm{W}=\text { bobot rata-rata ikan yang sebenarnya } \\
& \text { (g) } \\
& \mathrm{L} \quad=\text { panjang total rata-rata ikan }(\mathrm{cm}) \\
& \mathrm{a} \text { dan } \mathrm{b}=\text { konstanta }
\end{aligned}
$$


Pendugaan parameter pertumbuhan yang meliputi panjang asimtotik $\left(\mathrm{L}_{\infty}\right)$, indeks kurva pertumbuhan $(\mathrm{K})$, total mortalitas $(Z)$, mortalitas alami $(\mathrm{M})$, mortalitas penangkapan $(F)$, dan laju penangkapan $(E)$ dilakukan dengan menggunakan program FISAT II. Pertumbuhan ikan nila dianalisis dengan menggunakan rumus Von Bertalanffy (Sparre \& Venema, 1999) yaitu:

$$
L_{t}=L_{\infty}\left[1-e_{0}^{-K(t-t)}\right]
$$

Perhitungan total mortalitas menggunakan Beverton and Holt Z-Equation (Gayanilo et al., 2005) yaitu:

$\mathrm{Z}=\mathrm{K}\left(\mathrm{L}_{w}-\overline{\mathrm{L}} / \overline{\mathrm{L}}-\mathrm{L}^{\prime}\right)$

Mortalitas alami menggunakan rumus Pauly (1980) dalam (Gayanilo et al., 2005):

$\log (M)=-0,0066-0,279 \log \left(L_{\infty}\right)+0,654 \log$ $(\mathrm{K})+0,4634 \log (\mathrm{T})$

Mortalitas penangkapan didapatkan dari $\mathrm{F}=\mathrm{Z}-\mathrm{M}$, dan upaya penangkapan E=F/Z (Gayanilo et al., 2005).

di mana:

$\mathrm{L}_{\infty}=$ panjang asimtotik

$\mathrm{K}=$ percepatan pertumbuhan

$\mathrm{t}_{\mathrm{o}}=$ parameter kondisi awal

$\overline{\mathrm{L}}=$ panjang rata-rata ikan dalam contoh

$\mathrm{L}^{\prime}=$ panjang ikan terpendek dalam contoh

$\mathrm{T}=$ suhu rata-rata perairan

$\mathrm{Z}=$ total mortalitas

$$
\begin{aligned}
& \mathrm{F}=\text { mortalitas penangkapan } \\
& \mathrm{M}=\text { mortalitas alami } \\
& \mathrm{E}=\text { laju penangkapan }
\end{aligned}
$$

\section{HASIL DAN BAHASAN}

Ikan nila merupakan salah satu jenis ikan dari famili Chiclidae dan ordo Perciformes. Famili chiclidae sendiri merupakan ikan air tawar yang berasal dari Amerika Tengah dan Selatan, Afrika, Asia Kecil, India, dan Sri Lanka (Kottelat et al., 1993).

Ikan nila adalah jenis ikan tropis yang senang hidup di perairan yang dangkal. Batas suhu minimum dan maksimum untuk ikan nila $11-12^{\circ} \mathrm{C}$ dan $42^{\circ} \mathrm{C}$, dan dapat hidup pada suhu berkisar antara $31-36^{\circ} \mathrm{C}$ (Anonimus, 2009).

\section{Hubungan Panjang Bobot}

Hasil perhitungan antara hubungan panjang dan bobot ikan nila dapat dilihat pada Gambar 2. Tanpa membedakan jenis kelamin dari ikan nila, diperoleh persamaan $\mathrm{W}=0,129 \mathrm{~L}^{2,4608}$ dan persamaan lineamya adalah $\log W=-0,889+2 \cdot 461 \log L\left(r^{2}=0,8198\right)$. Setelah dilakukan uji $t$, nilai $t_{\text {hitung }}\left(t_{\text {hitung }}=386,77\right.$ ) lebih besar dari $_{t_{\text {table }}}\left(t_{\text {tabel }}=1.962\right)$ dengan tingkat kepercayaan 95\% yang artinya peningkatan pertambahan bobot tidak sebanding dengan pertambahan panjangnya.

Dari perhitungan tersebut dapat dikatakan bahwa ikan nila memiliki pola pertumbuhan allometrik negatif dengan nilai b yang lebih kecil dari $3(b=2.461)$, yang menunjukan bahwa pertambahan bobot dari ikan nila tidak secepat pertambahan panjangnya.

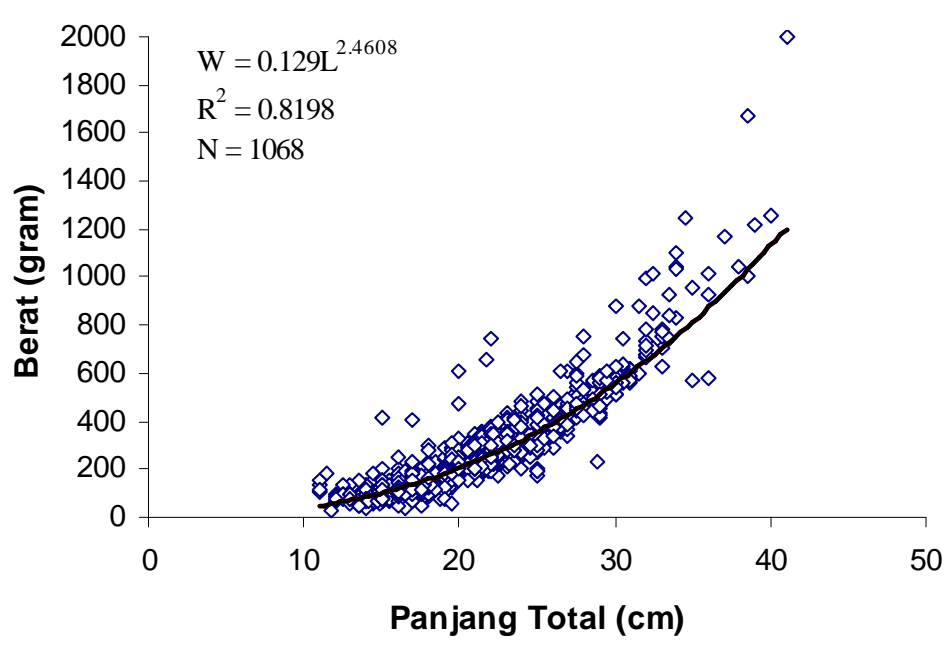

Gambar 2. Hubungan panjang bobot ikan nila (Oreochromis niloticus). Figure 2. Length weight relationship of nile tilapia (Oreochromis niloticus). 
Menurut Smith (1996) dalam Said (2007), analisis hubungan panjang bobot dari suatu populasi ikan mempunyai beberapa kegunaan, yaitu memprediksi bobot suatu jenis ikan dari panjang ikan yang berguna untuk mengetahui biomassa populasi ikan tersebut. Sedangkan menurut Effendie (1997), dari perhitungan panjang bobot ini dapat diduga bobot dari panjang ikan atau sebaliknya, keterangan tentang ikan mengenai pertumbuhan, kemontokan, dan perubahan dari lingkungan.

Pertumbuhan alometrik dari ikan nila di Waduk Ir. $\mathrm{H}$. Djuanda ini sama dengan pertumbuhan yang didapatkan dari tiga jenis ciclid lain (C. guntheri, Tilapia mariae dan Hemichromis fasciatus) di Nigeria Barat Daya (Olurin \& Sotubo, 1989). Tetapi sebaliknya, pertumbuhan dari juvenile ikan nila di Nigeria Barat Daya (Olurin \& Aderibigbe, 2006) dan jenis chiclid lain, ikan mujair (Oreochromis mossambicus) di Danau Ranau Sumatera Selatan (Utomo et al., 1990) adalah isometrik di mana $b=3$.

Koefisien regresi yang didapatkan dari hubungan panjang bobot tidak hanya berbeda antar spesies tetapi juga kadang berbeda dalam satu spesies yang sama. Perbedaan ini dapat dikarenakan perbedaan jenis kelamin, kematangan gonad, musim, dan kondisi lingkungan seperti polusi (Olurin \& Aderibigbe, 2006).

\section{Faktor Kondisi}

Faktor kondisi yang didapatkan dari data panjang bobot ikan nila 1,15. Nilai ini diartikan kondisi ikan nila di Waduk Ir. H. Djuanda memiliki badan yang kurang pipih atau agak montok. Hal ini dikatakan oleh Effendie (1997), ikan-ikan yang badannya kurang pipih memiliki harga $\mathrm{K}$ berkisar antara 1-3. Faktor kondisi dari ikan nila di Waduk Ir. H. Djuanda ini tidak jauh berbeda dengan rata-rata nilai faktor kondisi ikan nila di Nigeria yaitu 1,11 (Olurin \& Aderibigbe, 2006).

Nilai faktor kondisi dari ikan nila yang lebih dari satu juga mengindikasikan bahwa contoh ikan yang diobservasi berada dalam kondisi yang baik dan dapat digunakan untuk konsumsi. Menurut Olurin \& Aderibigbe (2006), jenis kelamin, musim, kondisi lingkungan, stres, dan ketersediaan makanan juga mempengaruhi faktor kondisi dari ikan. Salah satunya dibuktikan dari penelitian yang dilakukan oleh Stewart (1988) dalam Olurin \& Aderibigbe (2006), yang mengamati bahwa stres berdampak pada faktor kondisi ikan nila yang sangat rendah di Danau Turkena, Kenya.

\section{Distribusi Panjang Ikan Nila}

Gambar 3 menunjukan sebaran frekuensi panjang ikan nila di Waduk Ir. H. Djuanda selama bulan Pebruari sampai Nopember 2008. 

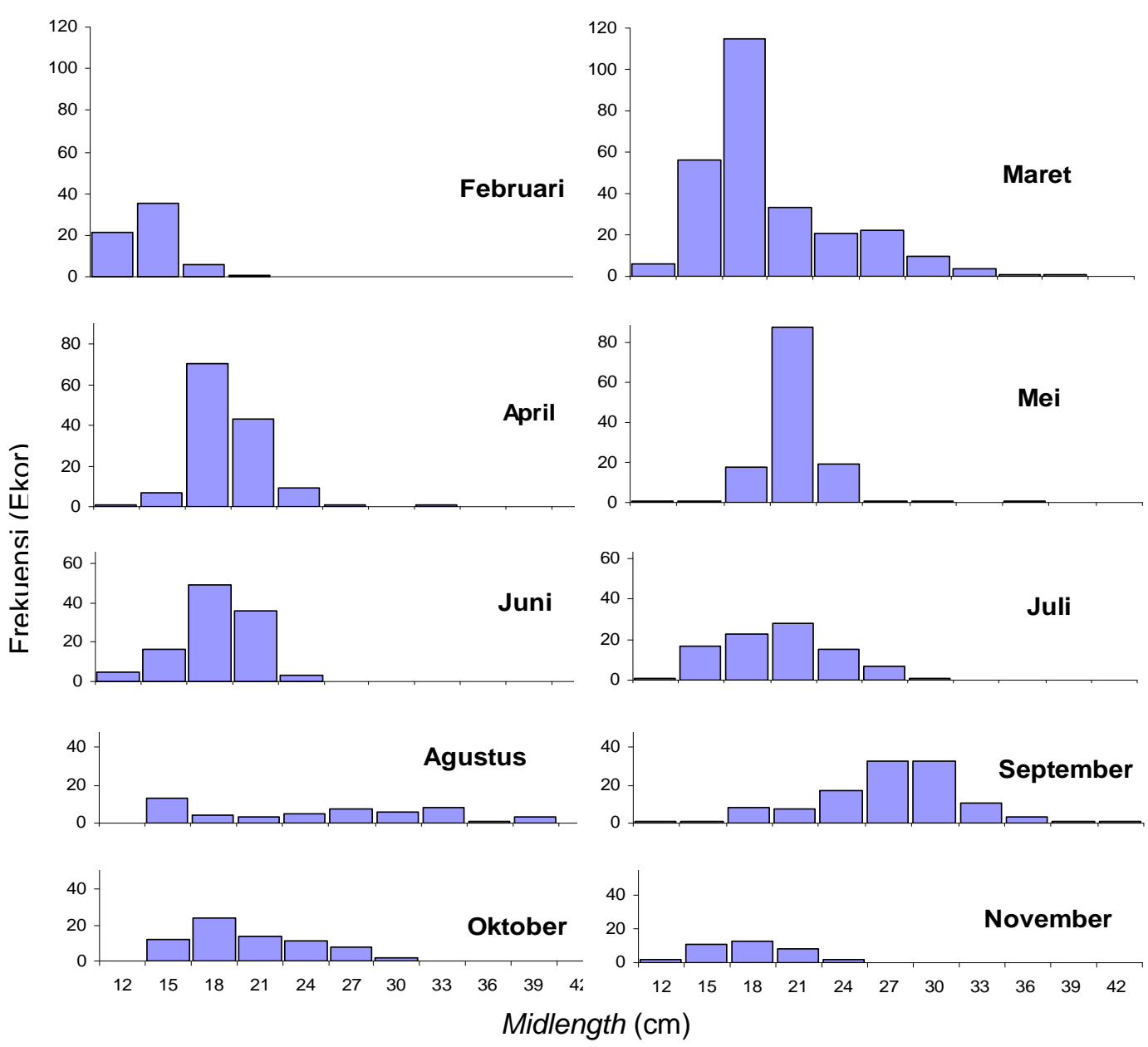

Gambar 3.

Midlength $(\mathrm{cm})$

Figure 3.

Distribusi bulanan ukuran panjang ikan nila (Oreochromis niloticus). Monthly length distribution of nile tilapia (Oreochromis niloticus).

Panjang total dari ikan nila yang tertangkap di Waduk Ir. H. Djuanda berkisar antara $11-41 \mathrm{~cm}$. Dari total ikan yang tertangkap, ikan dengan ukuran panjang kurang dari $25 \mathrm{~cm}$ mendominansi hasil tangkapan ikan nila di Waduk Ir. H. Djuanda. Sedangkan hasil tangkapan tertinggi ikan nila di Waduk Ir. H. Djuanda terjadi pada bulan Maret.

\section{Parameter Pertumbuhan}

Parameter pertumbuhan ikan nila di Waduk Ir. H. Djuanda yang didapatkan dari program FISAT II adalah $\mathrm{L}_{\infty}=44,10 \mathrm{~cm}$, percepatan pertumbuhan $(\mathrm{K})=0,72$ per tahun dan $\mathrm{t}_{0}=-0,2$ tahun, maka persamaan pertumbuhan panjang Von Bertalanffy dari ikan nila adalah $\mathrm{L}_{\mathrm{t}}=44,1\left[1-\mathrm{e}^{-0,72(t-(-0,2)}\right]$.
Berdasarkan atas persamaan tersebut, dapat dibuat suatu kurva pertumbuhan dari ikan nila (Gambar 4). Ikan yang banyak tertangkap selama pengamatan berukuran kurang dari $25 \mathrm{~cm}$ (Gambar 3), yang artinya umur ikan yang tertangkap berdasarkan atas persamaan di atas masih di bawah satu tahun. Pertumbuhan ikan nila yang ditemukan di Waduk Ir. $\mathrm{H}$. Djuanda sangat cepat selama tahun pertama dan kedua, kemudian semakin melambat setelah umur tiga tahun. Hal ini sesuai dengan yang dikatakan oleh Getabu (1992), bahwa pertumbuhan ikan nila melambat setelah tiga tahun, dengan sedikit sekali spesies yang dapat bertahan hidup. 


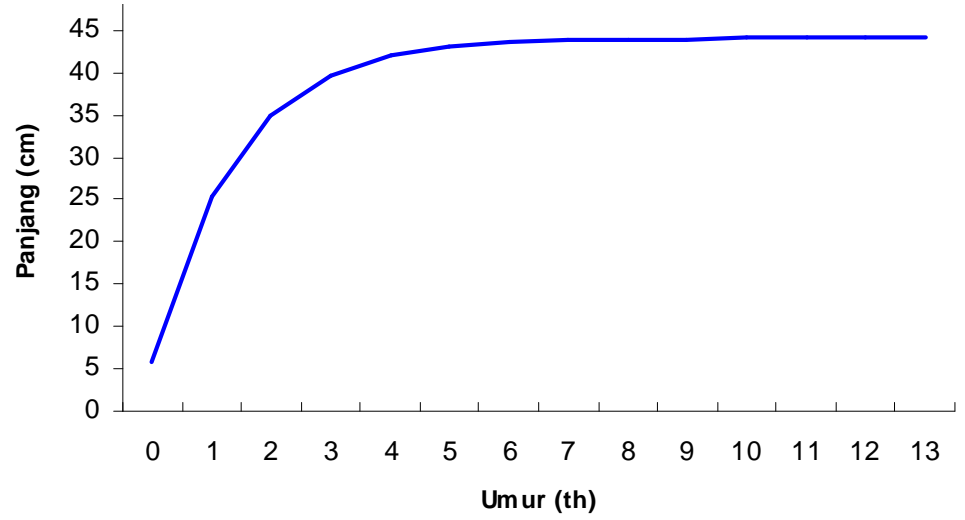

Gambar 4. Grafik pertumbuhan panjang ikan nila di Waduk Ir. H. Djuanda. Figure 4. Length growth grafik of nile tilapia in Ir. H. Djuanda Reservoir.

Pendugaan parameter pertumbuhan ikan nila juga pernah dilakukan di Danau Victoria, Kenya di mana panjang maksimum $\left(L_{\text {, }}\right)$ ikan nila yang ditemukan di sana oleh Njiru et al. (2007) mencapai $58,78 \mathrm{~cm}$ bahkan Getabu (1992) menemukan bahwa panjang ikan nila mencapai $64,6 \mathrm{~cm}$. Nilai ini tentu lebih tinggi bila dibandingkan dengan dugaan $\mathrm{L}_{\infty}$ ikan nila di Waduk Ir. H. Djuanda yang hanya mencapai $44,1 \mathrm{~cm}$.

Nilai K ikan nila di Waduk Ir. H. Djuanda 0,72 per tahun. Jika dibandingkan dengan penelitian Njiru et al. (2007); Getabu (1992), yang masing-masing nilai K-nya 0,59 dan 0,254 per tahun, maka nilai $\mathrm{K}$ ikan nila di Waduk Ir. H. Djuanda relatif lebih besar. Dapat dikatakan bahwa ikan nila di Waduk Ir. H. Djuanda tumbuh lebih cepat dibandingkan dengan ikan nila yang berada di Kenya. Hal ini diduga disebabkan ketersediaan pakan yang cukup di Waduk Ir. H. Djuanda bagi pertumbuhan ikan nila. Tetapi ikan nila di Waduk Ir. H. Djuanda mempunyai panjang asimtotik yang lebih kecil dibandingkan kedua penelitian tersebut. Nilai K sendiri merupakan suatu parameter yang menentukan seberapa cepat ikan mencapai panjang asimtotiknya (Sparre \& Venema, 1999).

Gambar 5 menunjukan grafik Von Bertalanffy Growth Function dari ikan nila dari program FISAT II.

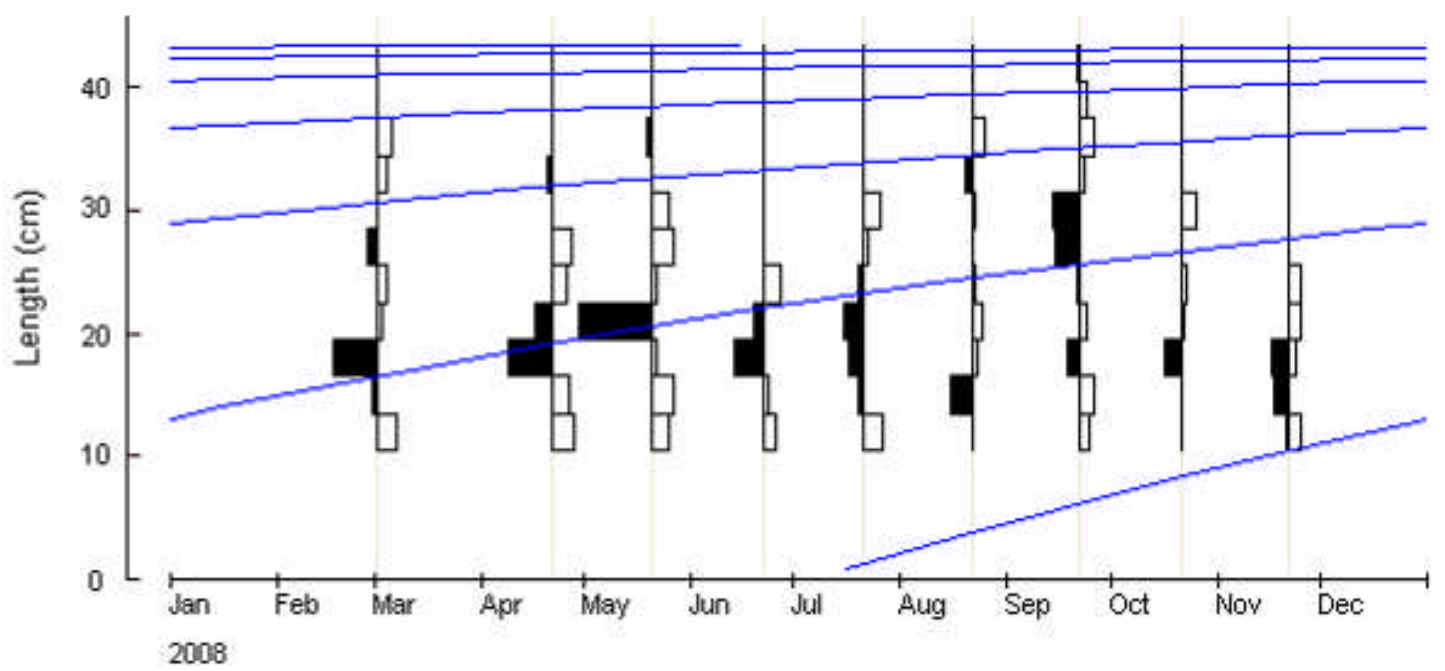

Gambar 5. Grafik Von Bertalanffy Growth Function dari ikan nila (Oreochromis niloticus).

Figure 5. Grafik of Von Bertalanffy Growth Function from nile tilapia (Oreochromis niloticus).

Dari grafik tersebut dapat diindikasikan bahwa rekruitmen (masuknya kohort baru dalam suatu populasi) ikan nila di Waduk Ir. H. Djuanda terjadi pada pertengahan bulan Juli. Pengamatan tentang reproduksi ikan nila di Waduk Ir. H. Djuanda sendiri belum pernah dilakukan, sehingga belum dapat dibandingkan dengan hasil dari grafik tersebut. Akan tetapi, rekruitmen ini sesuai dengan siklus hidup dari ikan nila yang ditemukan di Delta Nil yang memijah sekitar bulan April sampai Agustus (El Zarka et al., 1970 dalam Anonimus, 2007). 
Total mortalitas (Z) ikan nila yang didapatkan dari program FISAT II adalah 2,4 per tahun. Jika diasumsikan suhu rata-rata di Waduk Ir. H. Djuanda sekitar $30^{\circ} \mathrm{C}$, didapat nilai parameter mortalitas alami $(M)=1,34$ per tahun, mortalitas penangkapan $(F)=1,06$ per tahun dan laju penangkapan $(E)=0,44$ per tahun.

Jika dibandingkan dengan nilai M (laju kematian alami) ikan nila di Danau Victoria, Kenya $1 \pm 0,06$ per tahun (Njiru et al., 2007) maka tingkat kematian alami ikan nila di Waduk Ir. H. Djuanda lebih besar. Tingginya laju mortalitas alami di suatu perairan dapat disebabkan karena penurunan mutu perairan tersebut. Di Waduk Ir. H. Djuanda penurunan kualitas perairan disebabkan karena tingginya kadar polutan dan minimnya kadar oksigen terlarut dalam air (Kompas, 2009).

Menurut Gulland (1971) dalam Wouthuyzen et al. (1984), hasil tangkapan terhadap suatu populasi atau suatu stok ikan akan mencapai tangkapan yang lestari (MSY) jika mortalitas penangkapan sebesar mortalitas alami $(\mathrm{F}=\mathrm{M})$, dengan demikian rasio penangkapan akan mencapai optimal jika $E_{\text {opt }}=0,50$. Hasil perhitungan menunjukan $\mathrm{E}=0,44$ per tahun. Artinya laju tingkat penangkapan ikan nila di Waduk Ir. $\mathrm{H}$. Djuanda belum mencapai tahap lebih tangkap (over fishing) tetapi hampir mendekati optimal.

\section{KESIMPULAN}

1. Pola pertumbuhan ikan nila di Waduk Ir. H. Djuanda adalah alometrik negatif yang menunjukan bahwa pertambahan bobot dari ikan nila tidak secepat pertambahan panjangnya.

2. Ikan nila di Waduk Ir. H. Djuanda dalam kondisi yang baik dengan faktor kondisi 1,15.

3. Hasil pendugaan parameter pertumbuhan ikan nila di Waduk Ir. H. Djuanda didapatkan $L_{\infty}=44,1 \mathrm{~cm}$, $\mathrm{K}=0,72$ per tahun dan $\mathrm{t}_{0}=-0,2$ tahun. Dari persamaan Von Bertalanffy disimpulkan ikan nila tumbuh dengan cepat pada tahun pertama dan kedua.

4. Laju mortalitas didapatkan nilai $Z=2,4$ per tahun, mortalitas alami $\left(\mathrm{M}, \mathrm{T}=30^{\circ} \mathrm{C}\right)=1,34$ per tahun, mortalitas penangkapan $(F)=1,06$ per tahun, dan upaya penangkapan $(E)=0,44$ per tahun.

5. Upaya penangkapan ikan nila di Waduk Ir. H. Djuanda belum mencapai tahap lebih tangkap

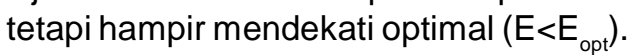

\section{PERSANTUNAN}

Tulisan ini merupakan kontribusi dari kegiatan riset biolimnologi dan hidrologi waduk kaskade Sungai Citarum, Jawa Barat, T. A. 2008, di Balai Riset Pemulihan Sumber Daya Ikan-Jatiluhur, Purwakarta.

\section{DAFTAR PUSTAKA}

Anonimus. 2007. Oreochromis niloticus-Nile Tilapia. Download www.el.erdc.usace.army.mil/86/ oreochromis_niloticus_nile_tilapia.htm. 29 Juli 2009

Anonimus. 2009. Cultured Aquatic Species Information Programme Oreochromis niloticus (Linnaeus, 1758). Download http://www.fao.org/ fishery/topic/13531/en 15 Juli 2009.

Effendie, M. I. 1997. Biologi Perikanan. Yayasan Pustaka Utama. Yogyakarta.

Gayanilo, F. C., P. Sparre, \& D. Pauly. 2005. FAOICLARM Stock Assessment Tools II Revised Version: User's Guide. Food and Agriculture Organization of the United Nations. Download ftp:/ /ftp.fao.org/docrep/fao/009/y5997e/y5997e07.pdf 28 Juli 2009.

Getabu, A. 1992. Growth parameters and total mortality in Oreochromis niloticus (Linnaeus) from Nyanza Gulf, Lake Victoria. Hydrobiologia. 232: 91-97.

Handayani, T. 2006. Aspek biologi ikan lais di Danau Lais. Journal of Tropical Fisheries. 1 (1): 12-23.

Kartamihardja, E. S. 2008. Perubahan komposisi komunitas ikan dan faktor-faktor penting yang mempengaruhi selama empat puluh tahun umur Waduk Djuanda. Jurnal Ikhtiologi Indonesia. 8 (2): 67-78.

Kottelat, M., J. W. Anthony, N. K. Sri, and W. Soetikno. 1993. Freshwater Fishes of Western Indonesia and Sulawesi (Ikan Air Tawar Indonesia Bagian Barat dan Sulawesi). Java Books. Jakarta. 170 pp.

Kompas. 2009. Mutu Air Waduk Mencemaskan. download http://www.ahmadheryawan.com/lintasjabar/lingkungan-hidup/4687-mutu-air-wadukmencemaskan.pdf. 5 Juli 2009. 
Njiru, M., Okeyo-Owuorb, Muchiria, Cowxc, \& an der Knaap. 2007. Changes in Population Characteristics and Diet of Nile Tilapia Oreochromis niloticus (I.) From Nyanza Gulf of Lake Victoria, Kenya: What are the Management Options?. Download http://www.informaworld.com/ smpp/content $\sim$ content $=$ a787301345 3 Agustus 2009.

Olurin, K. B. \& A. Sotubo. 1989. Pre-impoundment studies of the fishes of Owa Steam, South-west, Nigeria. Arch. Hydrobiol. 117: 107-116.

Olurin, K. B. \& O. A. Aderibigbe. 2006. Length weight relationship and condition factor of pond reared juvenile Oreochromis niloticus. World Journal of Zoology. 1 (2): 82-85. 2006 ISSN 1817-3098.

Said, A. 2007. Penelitian beberapa aspek biologi ikan serandang (Channa pleurophthalmus) di daerah aliran Sungai Musi, Sumatera Selatan. Neptunus $20.14(1): 15-23$.
Sparre, P. \& S. C. Venema. 1999. Introduksi Pengkajian Ikan Tropis. Buku 1: Manual. Pusat Penelitian dan Pengembangan Perikanan. Jakarta. $438 \mathrm{pp}$.

Sucipto, A. 2009. Pembenihan Ikan Nila. Download http://indoaqua.net/air-tawar/pembenihan-ikannila.html. 7 Agustus 2009.

Utomo, A. D., A. K. Gaffar, \& Samuel. 1990. Parameter Pertumbuhan, mortalitas, dan laju penangkapan ikan mujair (Oreochromis mossambicus) di Dananu Ranau, Sumatera Selatan. Bulletin Penelitian Perikanan Darat. 9 (2): 97-104.

Wouthuyzen, S., A. Suwartana, \& O. K. Sumadhiharga. 1984. Studi tentang populasi ikan kuri merah, Stolephorus heterolobus (Ruppel) dan kaitannya dengan perikanan umpan di Teluk Ambon bagian dalam. Oseanologi di Indonesia. 18: 1-20 ISSN 0125-9830. 